\title{
Origin and Metabolic Fate of Plasma Glycerol in the Rat and Rabbit Fetus
}

\author{
MARC' GILBF:RT ${ }^{(37)}$ \\ Laboratoire de' Physsiologie du Développement du College de France'. Université Pierre et Marie' Curie. \\ Paris, France
}

\begin{abstract}
Summary
On day 21.5 a pregnant rat received a single injection of $\mid 1$ ${ }^{14} \mathrm{C}$ lglycerol. The purpose was to study the transfer of glycerol through the placenta from the maternal to fetal plasma. From 3$20 \mathrm{~min}$ after injection the specific activity of glycerol in maternal and fetal plasma was measured. The results indicate that the mother can provide this molecule to the fetus. Similar results were obtained with the rabbit on day 28 of pregnancy.

The possibility of the conversion of plasma glycerol to glucose has been investigated in the rat and rabbit fetus. This molecule was chosen chiefly to see whether the gluconeogenic pathway was functioning in the fetus above the triose phosphate step.

At two stages of fetal development the capacity of the fetus to incorporate $[1-1+\mathrm{C}$ |glycerol into glucose plus glycogen has been shown in the two species.

In the rat fetus the conversion of $\mid 1{ }^{-14} \mathrm{C}$ |glycerol to $I^{14}$ Clglucose increases from 19.5 to 21.5 days of gestation. For the rabbit this parameter increases from 25 to 28 days of gestation.

On day 25 in the rabbit and day 19.5 in the rat the liver glycogen was labeled, but it did not accumulate the $\left[^{1+} \mathrm{C}\right]$ glucose from $\left[1-{ }^{14} \mathrm{C}\right.$ |glycerol during the time that we have studied. In contrast, on day 28 in the rabbit and day 21.5 in the rat the incorporation of radioactivity increased as function of the time.

However, the relative importance of glycerol as precursor of the glucose plus glycogen in the fetus remains to be elucidated.
\end{abstract}

\section{Speculation}

The available evidence suggests that in the fetal rat liver the gluconeogenesis does not appear until after birth. Quantitatively, the most important source of glucose for the fetus must be the mother.

The existence of glycerol in the plasma of the rat and rabbit fetus may contribute to produce glucose and increase liver glycogen reserves near term.

In the adult rat, the glycerol released from adipose tissue (7) is considered to be a substrate utilized in the gluconeogenic pathway (5). The study of adipose tissue metabolism in pregnant rats (whatever the diet) indicates that the lipid stores are mobilized to provide an alternative energy source for the mother $(18$, 25 ). As to the fate of the glycerol released from maternal adipose tissue, several authors suggested that it can serve as a source of energy for the fetus, but there is no positive information concerning the transfer of glycerol (23) from mother to fetus and its utilization by the fetus.

In the present experiment we studied, in two species (rat and rabbit), the placental transfer of glycerol from maternal to fetal plasma (21.5 days of gestation in the rat and 28 days of gestation in the rabbit) with a radioactive tracer. Since glycerol is a glucogenic substrate in the adult animal we measured $\left.{ }^{14} \mathrm{C}\right]$ glucose in the fetal plasma after administration of $11-$
${ }^{14} \mathrm{C}$ |glycerol to the fetus and its incorporation in fetal liver glycogen.

\section{MATERIALS AND METHODS}

The experiments were performed on albino rats (Sherman strain) and on rabbits (Fauve de Bourgogne). In rats, pregnant females were recognized by abdominal palpation according to the method of Jost and Picon (17) 14 days after cohabitation with a male. The rat experiments were done on day 21.5 or 19.5 of gestation and the rats were killed between 9 AM and $11 \mathrm{AM}$. In rabbits the age of gestation was reckoned from time of mating and the experiments were done on day 25 or day 28 of pregnancy.

The animals were anesthetized with pentobarbital $(30 \mathrm{mg} / \mathrm{kg}$ body weight ip in rats and $4.5 \mathrm{mg} / \mathrm{kg}$ iv in rabbits). A polyethylene catheter was inserted in a maternal carotid artery for blood sampling. Maternal and fetal blood samples were collected simultaneously between $3 \mathrm{~min}$ and $20 \mathrm{~min}$. The fetuses were successively exteriorized from the uterus, while the placenta and umbilical cord remained in situ. Fetal blood was collected with a heparinized micropipette after section of armpit vessels. Injections of labeled or unlabeled glycerol were made in a saphenous vein in rats and in an ear vein in rabbits.

\section{EXPERIMENTAL PROCEDURES}

[1-14 C |Glycerol (33), with a specific activity of $57 \mathrm{mCi} / \mathrm{mmol}$, was used.

Injection of $/ 1^{-1+} C / G l y c e r o l$ into the Mother. A single dose of radioactive glycerol was injected rapidly $(10 \mu \mathrm{Ci}$ in $0.1 \mathrm{ml}$ in rats; $50 \mu \mathrm{Ci}$ in $0.2 \mathrm{ml}$ in rabbits) and the specific activity of plasma glycerol was measured in maternal and in fetal plasma.

Injection of $/ 1-{ }^{14} /$ Glycerol into the Fetus. [1-14 C ]Glycerol was injected into the fetus through a vitelline vein using the technique described by Petter and Bourbon (20). Fetal and maternal blood were collected between 5 and 20 min after injection.

\section{BIOCHEMICAL PROCEDURES}

An aliquot of blood (0.02 ml) was immediately deproteinized in cold barium hydroxide-zinc sulfate (27) and filtrates were used for glucose determination with the glucose oxidase method (14). The remainder of the blood was centrifuged $(12,000 \times g)$ at $4^{\circ}$ for $2 \mathrm{~min}$. A first aliquot of the plasma $(0.05 \mathrm{ml})$ was used for estimation of glycerol by an enzymatic fluorimetric method (19). A second aliquot of plasma was deproteinized with a crystal of $\mathrm{ZnCl}_{2}$. After centrifugation the protein-free supernatant was mixed with an equal volume of methanol and spotted on to Whatman no. 1 paper ( 4 by $36 \mathrm{~cm}$ ) for separation of glucose and glycerol. Descending chromatography was run for $18 \mathrm{hr}$ with propanol 2 -ol-ethyl acetate-water $(7: 2: 1$ by volume) $(28)$. The chromatograms were passed through a chromatograph scanner (34) for the detection of the $\left.\right|^{14} \mathrm{C} \mid g l u c o s e$ and $\left[1-1^{14} \mathrm{C}\right] \mathrm{glycerol}$ peaks. Actually, only two bands of radioactivity were found on the chromatograms, one with the same $R_{F}$ as glucose and the 
other with that of glycerol. Each band of the radioactivity was cut into $2-\mathrm{cm}$ strips, which were placed in vials containing $1 \mathrm{ml}$ of water. One hour later, $97 \%$ of the radioactivity was present in the eluate. A scintillation fluid (10 $\mathrm{ml}$ PCS solubilizer (35)) was added to each vial and the radioactivity was measured with $80 \%$ efficiency in a Nuclear Chicago spectrometer (Mark I). In some experiments, the chromatographic separation of glucose from glyeerol was verified. The eluates of the band corresponding to glucose were incubated with glucose oxidase; the concentration of glucose was identical with that obtained from blood directly.

After collection of fetal blood, the liver was rapidly removed for the determination of liver glycogen. A liver sample was frozen in liquid nitrogen, and the glycogen concentration was measured by the enzymatic technique of Roehrig and Allred (22) with amyloglucosidase (EC. 3.2.1.33, $\alpha$-1.4, $\alpha$-1,6-glucan glucohydrolase. The radioactivity contained in the liver glycogen was estimated after extraction with hot potassium hydroxyde $(60 \%)$ and two precipitations with ethanol $95 \%$. The precipitate was dissolved in $2 \mathrm{ml}$ water. An aliquot of the solution was added to the scintillation fluid.

\section{CALCUI.ATION}

The specific activities (SA) of glucose and glycerol were calculated as follows

$$
\mathrm{SA}=\frac{\text { counts per min as glycerol (or glucose }) / 0.1 \mathrm{ml} \text { plasma }}{\mathrm{nM} \text { as glycerol (or glucose }) /(0.1 \mathrm{ml} \text { plasma }}
$$

For statistical evaluation of the results, the unpaired Student $t$ test was used.

\section{RESULTS}

\section{PLACENTAL TRANSFER OF $\mid 11^{1+}(\mid)$ GLYCEROL FROM} MOTHER TO FETUS

Rats. When $\left.\right|^{14} \mathrm{C} \mid \mathrm{glyce}$ (e) was injected into pregnant rats at 21.5 days of gestation it rapidly appeared in the fetal plasma (Fig. 1). After only 2 and for a period of $20 \mathrm{~min}$ the specific activity of glycerol in the fetal plasma was approximately equal to or slightly higher than that in the maternal plasma (Fig. 1).

Rabbits. The placental transfer of $\left[^{1+4}(\mathrm{C} / \mathrm{glycerol}\right.$ was studied in only one litter. $\left|1-{ }^{14} \mathrm{C}\right|$ Glycerol injected into a pregnant rabbit on day 28 of pregnancy rapidly appeared in the fetal plasma (Fig. 2). Between 2 and $12 \mathrm{~min}$ after the injection the specific activity of glycerol was approximately the same in maternal and in fetal plasma (Fig. 2).

\section{EFFECT OF MATERNAL HYPERGLYCEROLEMIA ON FETAL BLOOD GLYCEROL}

After the injection of a large dose of glycerol in the pregnant rat there is a proportionality between the fetal and maternal glycerolemia (Fig. 3).

\section{PLACENTAL TRANSFER OF $\left[1\right.$ - $\left.^{14} \mathrm{C}\right] \mathrm{GLY}$ (EROL FROM THE FETUS TO THE MOTHER}

Rats. The $\left[1-{ }^{14} \mathrm{C}\right]$ glycerol $(5 \mu \mathrm{Ci})$ was injected in two fetuses in each litter. The amount of radioactivity that appeared in the plasma of the mother and of the noninjected littermate fetuses was very low (Table 1). The very low quantity of total radioactivity in maternal blood did not allow detection of $\left[1-{ }^{-14} \mathrm{C}\right]$ glycerol and $\left[{ }^{1+} \mathrm{C}\right]$ glucose after chromatography. In order to determine the specific radioactivity of these compounds in the maternal plasma it was necessary to inject a much higher dose of 11 ${ }^{14} \mathrm{C}$.glycerol into the fetus. By chance we found two pregnant rats that had only one fetus. This provided a system comprising two compartments: the fetus and the mother. In these experiments $12 \mu \mathrm{Ci}\left[1{ }^{14} \mathrm{C}\right]$ glycerol was injected into the fetus. Between 5 and 22 min after the injection, the specific activity of glycerol in the maternal plasma increased slightly, but it was only
$0.2 \%$ of that measured in the fetal plasma 22 min after injection (Fig. 4). There seems to be little transfer from fetus to mother.

Rabbits. $\left[1-{ }^{14} \mathrm{C}\right]$ Glycerol $(5 \mu \mathrm{Ci})$ was injected in two fetuses per litter. The amount of radioactivity that appeared in the plasma of the mother and of the noninjected littermate fetuses was very low (Table 1).

\section{CONVERSION OF GLYCIRROL TO GLUCOSE IN THE FETUS}

In the rat experiment with a single fetus present, described in Figure 4 , the presence of $\left.\right|^{1.4} \mathrm{C} \mid$ glucose was also observed in the maternal and fetal plasma. Twenty-two minutes after the injection of $\left[1-{ }^{14} \mathrm{C} \mid \mathrm{glyc}\right.$ yerol, the specific activity of glucose was about

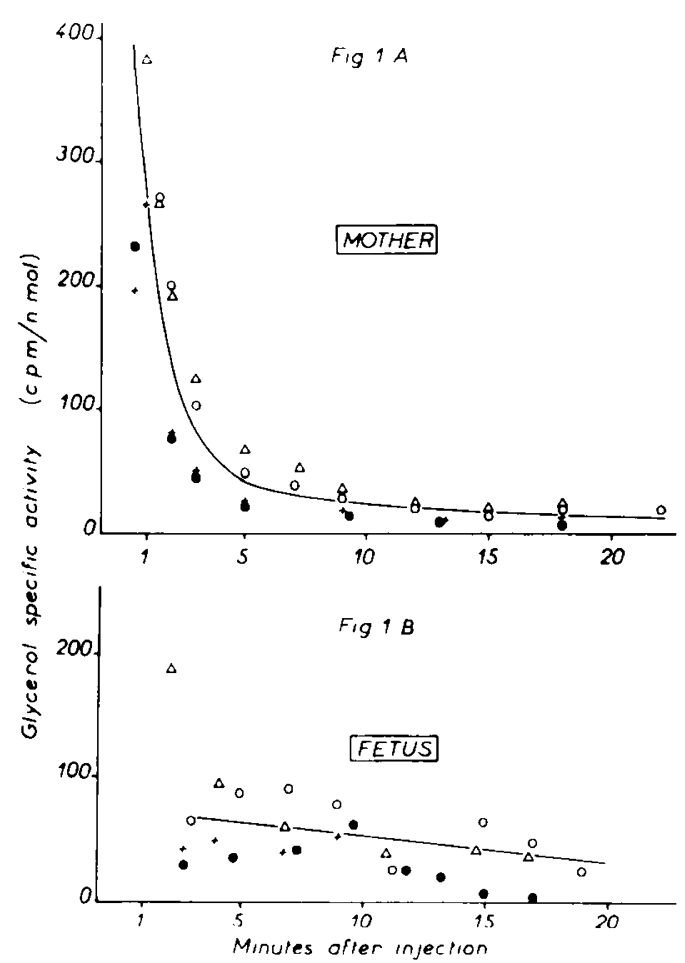

Fig. 1. Transfer of $\left[1-{ }^{-14}(\mathrm{C}) \mathrm{glyce}\right.$ rol across the rat placenta from mother to fetus. Similar signs $(\triangle, O,+, \bullet)$ represent measurements in the same mother and her fetuses at 21.5 days of gestation. The specific activity of glyeerol versus time in maternal plasma is shown in $A$ (the curve was drawn by eye) and in fetal plasma in $B$ (the straignt line was fitted to the points by the least squares method).

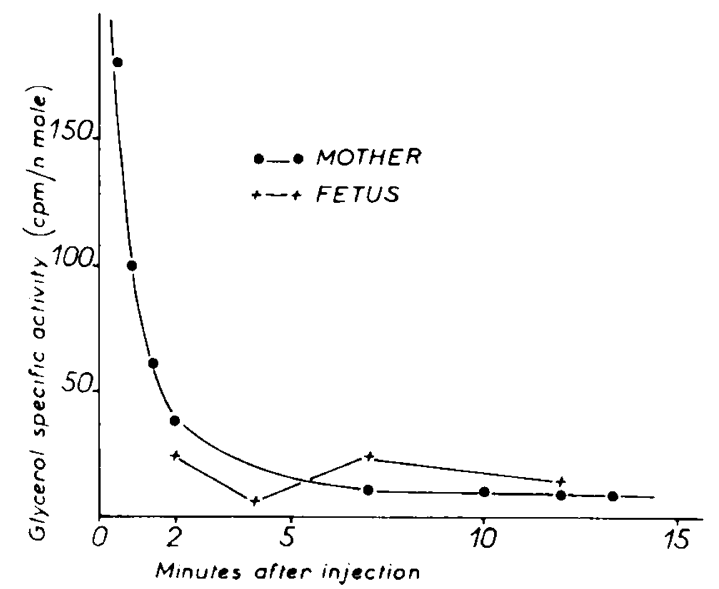

Fig. 2. Transfer of $\left.{ }^{14} \mathrm{C}\right]$ glycerol across the rabbit placenta from mother to fetus in one litter on day 28 of pregnancy. The specific activity of glycerol in the maternal and fetal plasma is reported as function of the time. 


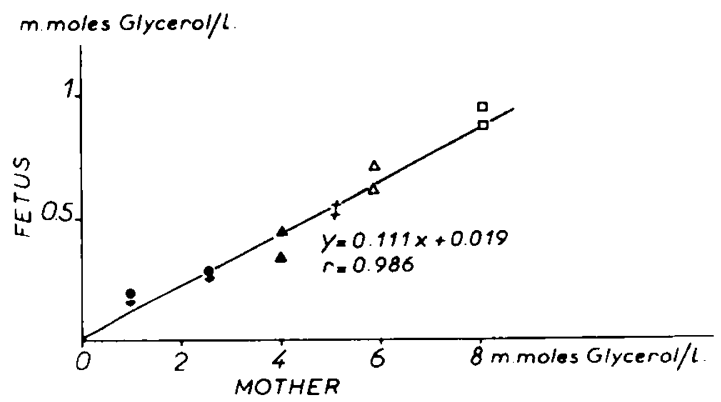

Fig. 3. Effect of maternal hyperglycerolemia on fetal blood glycerol. A high dose of glycerol was injected into the mother. The maternal and the fetal blood was collected between 2 and $3 \mathrm{~min}$ after the injection. Identical symbols represent the plasma glycerol concentration of one rat and its fetuses (2).

Table 1. Amount of radioactivity recovered in maternal plasma and control fetus expressed in percentage of radioactivity of 11 ${ }^{14}$ Clglycerol, injected into fetus ${ }^{1}$

\begin{tabular}{cccc}
\hline Gestational age, days & Control fetus & Mother \\
\hline Rat & 19.5 & $2.8(2)$ & $5.0(2)$ \\
& 21.5 & $2.7(10)$ & $3.1(6)$ \\
Rabbit & 25 & $1.3(3)$ & $3.5(3)$ \\
& 28 & $0.8(7)$ & $3.7(4)$ \\
\hline
\end{tabular}

' The results are given with the numbers of observations in parentheses.

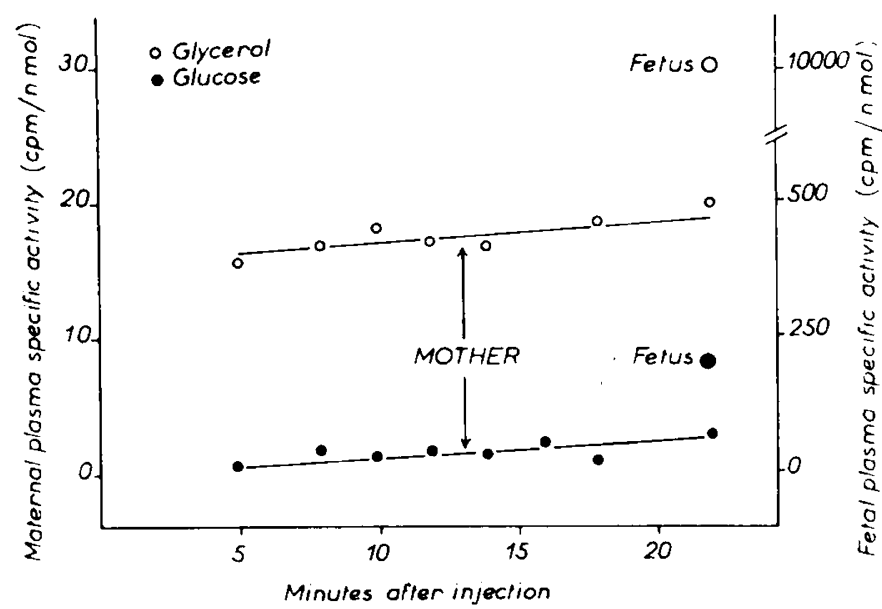

Fig. 4. Specific activity of $\left[{ }^{14} \mathrm{C}\right)$ glycerol and $\left[{ }^{1+} \mathrm{C}\right]$ glucose in maternal and fetal plasma of rat at 21.5 days of gestation, after the injection of 12 $\mu \mathrm{Ci}$ into the only fetus in the "litter"). Each point represents the mean value of two experiments. In maternal plasma the determinations are reported as function of the time. In fetal plasma one single determination was made $22 \mathrm{~min}$ after the injection.

70 -fold greater in the fetus than in the mother. This figure rules out the maternal origin of $\left[^{14} \mathrm{C}\right]$ glucose; therefore, it can be concluded that the fetus was capable of converting glycerol into glucose.

Other experiments were made in rats and in rabbits.

Rats. When $\left[1-{ }^{14} \mathrm{C}\right]$ glycerol was injected into the fetus at two stages of gestation, conversion of $\left[11^{14} \mathrm{C}\right]$ glycerol to $\left[{ }^{14} \mathrm{C}\right]$ glucose was observed. The percentage of radioactivity isolated as $\left[{ }^{14} \mathrm{C}\right]$ glucose increased as a function of the time. Ten minutes after the injection of $\left[1-{ }^{14} \mathrm{C}\right]$ glycerol, the percentage in plasma of the 21.5-day-old fetus was twice that of the 19.5-day-old fetus. Maximum labeling of glucose occurred at 21.5 days of gestation and $10 \mathrm{~min}$ after the infection of glycerol (Fig. 5).

Rabbits. Conversion of glycerol to glucose after injection of $\left[1-{ }^{14} \mathrm{C}\right] \mathrm{glyce}$ rol into the rabbit fetus also occurred. The rate of conversion 10 or $20 \mathrm{~min}$ after the injection was higher on day 28 of gestation than on day 25 (Fig. 6).

\section{INCORPORATION OF RADIOACTIVITY IN LIVER GLYCOGEN OF FETUS}

Rats. In the 19.5-day-old fetus the total amount of radioactivity incorporated per $\mathrm{g}$ liver decreased between 10 and $20 \mathrm{~min}$ after the injection of $\left[1-^{14} \mathrm{C}\right]$ glycerol $(P<0.02)$ (Fig. 7a). In contrast, at 21.5 days of gestation there was an increase of the total amount of radioactivity incorporated per $\mathrm{g}$ liver $(P<$ (0.05). If the incorporation results are expressed as counts per min per mg glycogen (Fig. $7 b$ ) the vilues are not significantly different 10 and $20 \mathrm{~min}$ after the injection for the 19.5-day-old fetus, whereas with the 21.5-day-old fetus there is an increase of this parameter between 10 and $20 \mathrm{~min}$.

Rabbits. In 25-day-old fetuses, 10 and $20 \mathrm{~min}$ after injection of $\left[1-{ }^{14} \mathrm{C}\right]$ glycerol, the incorporation of radioactivity expressed as counts per min glucose per $\mathrm{g}$ liver (Fig. $8 a$ ) or counts per min glucose per mg glycogen (Fig. $8 b$ ) was the same. In contrast, on day 28 , the specific radioactivity level of the glycogen was twice as high at $20 \mathrm{~min}$ than at $10 \mathrm{~min}$ and the total amount of radioactivity per $\mathrm{g}$ liver was 3 times as much.

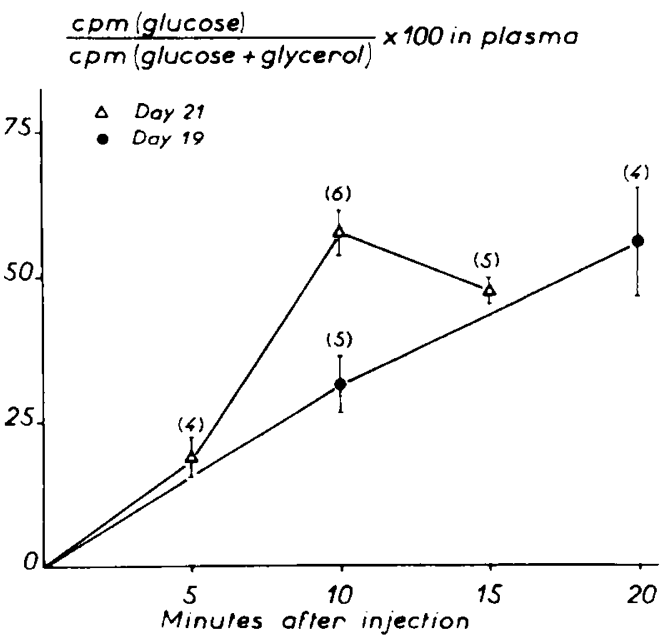

Fig. 5. Percentage of total radioactivity as $\left[{ }^{14} \mathrm{C}\right] \mathrm{glucose}$ in the fetal plasma after injection of $\left[1{ }^{14} \mathrm{C}\right] \mathrm{glycerol}(5 \mu \mathrm{Ci})$ at two stages of gestation in the rat fetus. The results are expressed as means \pm SEM with the numbers of fetuses in parentheses.

$$
\frac{c p m \text { glucose }}{c p m \text { glucose }+ \text { glycerol }} \times 100 \text { in plasma }
$$

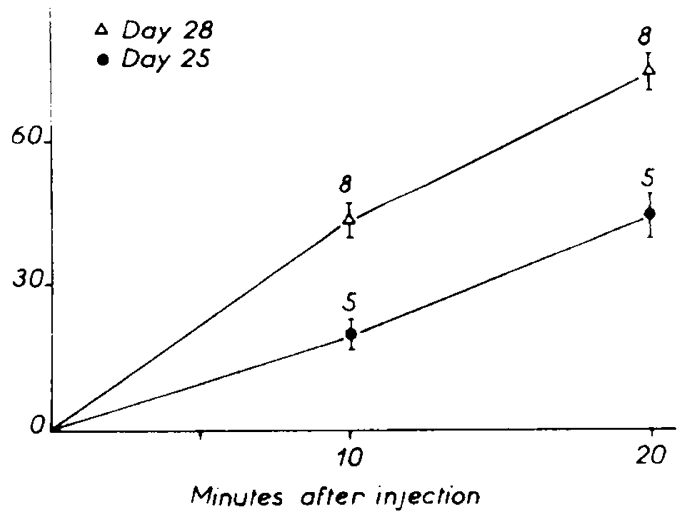

Fig. 6. Percentage of total radioactivity as $\left[{ }^{14} \mathrm{C} /\right.$ glucose in the fetal plasma after injection of $\left[1{ }^{14} \mathrm{C}\right] \mathrm{glycerol}(5 \mu \mathrm{Ci})$ at two stages of gestation in the rabbit fetus. The results are expressed as means \pm SEM with the numbers of fetuses in parentheses. 


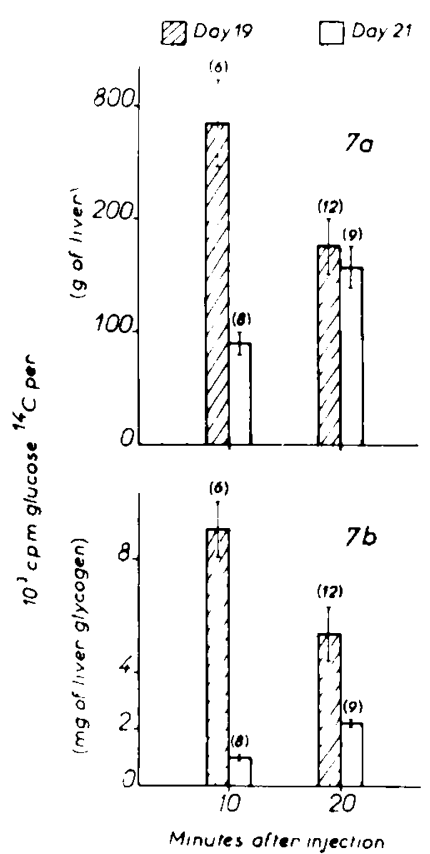

Fig. 7. Incorporation of radioactivity into the liver glycogen of the rat fetus at 19.5 and 21.5 days of gestation. The fetus received $5 \mu \mathrm{Ci}$ of $\left[1-{ }^{14} \mathrm{C}\right]$ glycerol as in the experiment described in Figure 5. The results are expressed as means \pm SEM with the numbers of fetuses in parentheses.

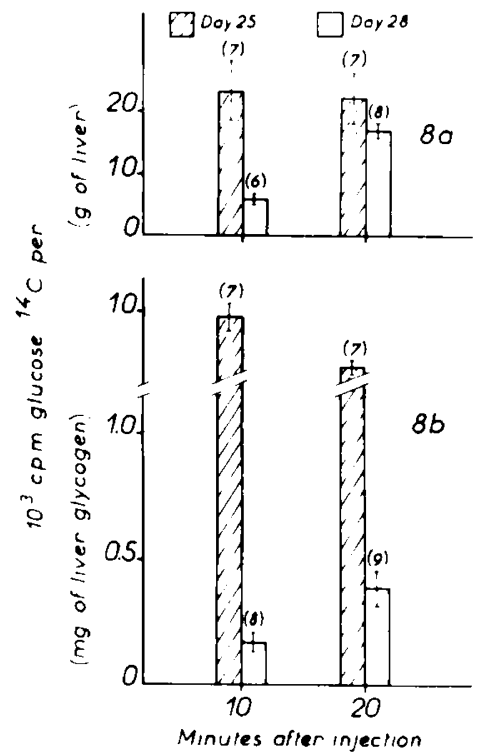

Fig. 8. Incorporation of radioactivity into the liver glycogen of the rabbit fetus on day 25 and on day 28 of gestation. The fetuses which were studied in this experiment are the same that those used in the experiment described in Figure 6 . The results are expressed as means \pm SEM with the numbers of fetuses in parentheses.

\section{DISCUSSION}

\section{PLACENTAL TRANSFER OF GLYCEROL}

$\left[1-{ }^{14} \mathrm{C}\right]$ Glycerol injected into the mother is rapidly transferred across the placenta in the two species (Fig. 1 and Fig. 2). The transport is not saturated between the physiologic and supraphysiologic concentrations of unlabeled glycerol (Fig. 3). A gradient of glycerol between maternal and fetal blood observed in these two species (Table 2) was also noted in the human fetus by Sabata et al. (24). However, these authors could not establish a transfer when they studied the correlation between maternal and fetal glycerol levels. Their values were obtained during delivery and in hypoxic situation. The release of glycerol from fetal adipose tissue may mask the transfer from mother to fetus. In our expriments the glycerol production by the fetus was probably negligible, since in the term rat fetus the white adipose tissue is absent and the brown adipose tissue represents about $1 \%$ of the body weight (12). In the rabbit fetus at term the fat stores are more important and represent about $6 \%$ of the body weight $(30)$, but the glycerol production by the fetus was probably negligible as in the rat fetus.

The presence of glycerol in the blood of the rat fetus requires a transfer of the molecule through the placenta, from the maternal to the fetal plasma. The observation that very little radioactivity was recovered in the maternal plasma after injection of 11${ }^{14} \mathrm{C}$ lglycerol in the fetus might suggest that the placenta is less permeable to glycerol in this direction. However, it should be taken into account that $\left[1-{ }^{14} \mathrm{C}\right]$ glycerol originating from the fetus is diluted in a large maternal volume. From the data reported in Table 1, a rough estimate of amount of radioactivity can be made. For the pregnant rat, at term, the body weights of the mother and the fetus were about $300 \mathrm{~g}$ and $5 \mathrm{~g}$, respectively. The dilution space of glycerol represents $190 \mathrm{ml}(65 \%$ of the body weight (26)) for the mother and $3 \mathrm{ml}$ for the fetus. On the basis of glycerol pool size, if $100 \mathrm{cpm}$ of radioactivity were distributed in a space of $3 \mathrm{ml}$ fetal plasma, the radioactivity distributed in the mother will be about $120-150 \mathrm{cpm} / 190 \mathrm{ml}$ plasma. Similar results were obtained with the rabbit. It is likely that the transfer of glycerol from the mother to the fetus is overestimated, because we have not dissociated the glucose and glycerol. From the data obtained in Figure 4, $22 \mathrm{~min}$ after the injection of 11 ${ }^{14} \mathrm{C}$ |glycerol into the fetus, about $7.5 \times 10^{5} \mathrm{cpm}$ of glycerol are distributed in the pool of the mother and $22 \times 10^{5} \mathrm{cpm}$ in the fetus, indicating that the transfer of the molecule is low but not negligible.

\section{CONVERSION OF GLYCEROL TO GLUCOSE IN FETUS}

The liver of the rat fetus has been reported to be incapable of gluconeogenesis from pyruvate (3); this metabolic pathway does not appear until after birth $(31,32)$ because of the absence of the key enzyme, phosphoenolpyruvate carboxykinase (1). However, the enzymes involved in the conversion of glycerol to glucose in the adult animal, namely glycerol kinase $(11,29)$, fructose-1.6-diphosphatase (2), and glucose-6-phosphatase (8) are present with a non-negligible activity in the fetal liver. In vitro studies of gluconeogenesis with liver or kidney slices have shown that gluconeogenesis from glycerol occurs only after birth in the rat (28). Similarly, in vivo the liver of the rat fetus was unable to convert glycerol into glucose 2 days before birth (6). The conversion occurred in fetuses which had been delivered surgically 1 day before term $45 \mathrm{~min}$ after delivery. So far there is no information concerning enzymatic activities involved in conversion of glycerol to glucose in the rabbit fetus.

Our results are not in agreement with these earlier observations as we noted that the gluconeogenic pathway was functional in the rat and rabbit fetus, above the triose phosphate step (at least at the gestational stages studied). This discrepancy might be explained in part by the methodology. Thus, using glycerol in trace amounts one may label the metabolic pathway without modification of glycerol level in the blood.

Table 2. Plasma glycerol in rat and rabbit fetuses and in their dams ${ }^{1}$

\begin{tabular}{cccc}
$\begin{array}{c}\text { Gestational age, } \\
\text { days }\end{array}$ & \multicolumn{1}{c}{ Fetus } & Mother \\
\hline Rat & 19.5 & $69.2 \pm 8.4(8)$ & $160.5 \pm 17.5(2)$ \\
& 21.5 & $64.8 \pm 5.6(8)$ & $164.5 \pm 27.4(4)$ \\
Rabbit 25 & $238.6 \pm 21.4(15)$ & $581.0 \pm 163.0(3)$ \\
& 28 & $258.8 \pm 15.7(17)$ & $545.6 \pm 46.0(6)$ \\
\hline
\end{tabular}

'Values in micromoles \pm SEM, with the numbers of cases in parentheses. 
Under conditions of starvation or of low carbohydrate diet in the mother, the conversion of glycerol might play an important role for the fetus. According to the research of Girard (10) starvation of the pregnant rat during the last 4 days of gestation produced a 2 -fold rise of glycerol in maternal plasma, but no similar modification could be detected in the fetal plasma. Conversion of glycerol to glucose in the fetus has not been studied. Ward and Walker (29) have shown that there is considerable increase in the activity of liver glycerol kinase $5 \mathrm{hr}$ after injection of glycerol into the fetus (in utero) on the last day of gestation. Since the fetus needs large amounts of glucose, fetal gluconeogenesis from glycerol may be vital in the starving mother.

\section{INCORPORATION OF RADIOACTIVITY IN FETAL LIVER GLYCOGEN}

The possibility that glycerol is used for the synthesis of glycogen has been shown by Plas (21) in primary culture of rat fetal hepatocytes. We confirm this observation in the present study. The synthesis of glycogen from glycerol may occur without formation of glucose (13). The importance of this pathway could not be appreciated in our experiments.

On day 28 in the rabbit (Fig. $8 b$ ) and on day 21.5 in the rat (Fig. $7 b$ ), the specific radioactivity of glycogen 10 and $20 \mathrm{~min}$ after the injection of $\left[1-^{14} \mathrm{C}\right]$ glycerol increased in parallel with the total amount of radioactivity in the liver. This result may indicate that the turnover of glycogen was low. On day 25 (in the rabbit) the incorporation of radioactivity into glycogen (Fig. $8 a$ and $b$ ) did not change significantly between 10 and $20 \mathrm{~min}$. In this species glycogen storage in the liver begins between days 25 and $26(16)$; the absence of further incorporation of radioactivity after $10 \mathrm{~min}$ might result from a dynamic equilibrium between glycogen synthesis and degradation at that stage. In the 19.5day-old rat (Fig. $7 b$ ) the decrease of the specific activity of glycogen between 10 and $20 \mathrm{~min}$ might be explained by the rapid process of glycogen synthesis (14). The disappearance of the radioactivity in the liver (Fig. $7 a$ ) would suggest a rapid turnover of glycogen, although a low turnover is generally reported (9). However, it is impossible to ascertain which part of the molecule is renewed in the fetus. In our experimental conditions the fetus was probably anoxic (as a result of maternal anesthesia), and it is possible that the radioactivity at the extremities of the outer chains of glycogen tended to disappear rapidly, as it has been shown in the adult rat (4) after an injection of $\left[{ }^{14} \mathrm{C}\right]$ glucose.

\section{CONCLUSION}

The present paper describes experiments which were designed to measure the transfer of glycerol through the placenta from the maternal to fetal plasma in two species (rat and rabbit).

About $2 \mathrm{~min}$ after the intravascular injection of 11 ${ }^{14} \mathrm{Clglycerol}$ into the mother, the radioactivity appeared in the fetal plasma. In view of this result we have studied the fate of glycerol molecule in the fetal plasma.

The intravascular injection of $\left[1-{ }^{14} \mathrm{C}\right] \mathrm{g} l y c e r o l$ into the fetus at two stages of the gestation (at days 19.5 and 21.5 in the rat, and at days 25 and 28 in the rabbit) indicated the ability of the fetus to convert glycerol to glucose plus glycogen. The gluconeogenic pathway was functioning above the triose step, and it is possible that the glycerol must be a more or less significant precursor of endogenous body glucose in the fetus. Measurements of $\left[{ }^{14} \mathrm{C}\right]$ glucose incorporation into liver glycogen suggest that the glycerol might play a role in glycogenesis, but the quantitative aspect remains to be elucidated.

\section{REFERENCES AND NOTES}

1. Ballard, F. J., and Hanson, R. W.: Phosphoenolpyruvate carboxykinase and pyruvate carboxylase in the developing rat liver. Biochem. J., 104: 866 (1967).
2. Ballard, F. J., and Oliver, I. T.: Appearance of fructose-1,6-diphosphatase in postnatal rat liver. Nature, 195: 498 (1962).

3. Ballard, F. J and Oliver, I. T.: GLycogen metabolism in embryonic chick and neonatal rat liver. Biochim. Biophys. Acta, 71: 578 (1963)

4. Birch, G. G., Lee, E. Y. C., and Hems, D. A.: Structure and turnover of rat hepatic glycogen during metabolic activity. Int. J. Biochem. . 5: 867 (1974)

5. Borchgrevink, C. F., and Havel, R. J.: Transport of glycerol in human blood. Proc. Soc. Exp. Biol., N. Y., 113: 946 (1963).

6. Bossi, E., and Greenberg, R. E.: Sources of blood glucose in the rat fetus. Pediat. Res., 6: 765 (1972).

7. Carlson, L. A., and Orö, L.: Studies on the relationship between the concentration of plasma free fatty acids and glycerol in vivo. Metabolism, 12: 132 (1963).

8. Dawkins, M. J. R.: Biochemical aspects of developing function in newborn mammalian liver. Brit. Med. Bull., 22: 27 (1966).

9. Devos, P., and Hers, H. G.: Glycogen metabolism in the liver of the fetal rat. Biochem. J., 140: 331 (1974)

10. Girard, X:: Unpublished observations.

11. Hahn, P., and Greenberg, R. E.: The development of pyruvate kinase and phosphoneolpyruvate carboxykinase activities in liver and adipose tissue of the rat. Experientia, 24: 428 (1968).

12. Hemon, P.: Etude de quelques aspects du métabolisme énergétique chez le rat blanc au cours du développement: Influence de l'état thyroidien (Thèse de Doctorat d'Etat, Université Pierre et Marie Curie, 1973)

13. Hems, D. A. Whitton, P. D., and Taylor, E. A.: GLycogen synthesis in the perfused liver of the starved rat. Biochem. J., 129: 529 (1972).

14. Huggett, A.S. G., and Nixon, D. A.: Use of glucose oxidase, peroxidase and O-dianisidine in determination of blood and urinary glucose. Lancet, ii: 368 (1957).

15. Jacquot, R.: Recherches sur le controle endocrinien de l'accumulation de glycogène dans le foie chez le foetus de rat. J. Physiol. (Paris), 51: 655 (1959).

16. Jost, A., and Jacquot, R.: Recherches sur les facteurs endocriniens de la charge en glycogène du foie foetal chez le lapin (avec des indications sur le glycogène placentaire). Ann. Endocrinol., 16: 849 (1955).

17. Jost, A., and Picon, L.: Hormonal control of fetal development and metabolism. Advan. Metabol. Dis., 4: 123 (1970)

18. Knopp, R. H., Saudek, C. D., Arky, R. A., and O'Sullivan, J. B.: Two phases of adipose tissue metabolism in pregnancy: Maternal adaptation for fetal growth. Endocrinology, 92: 984 (1973).

19. Laurell, S., and Tibling, G.: An enzymatic fluorometric micromethod for the determination of glycerol. Clin. Chim. Acta, 13: 317 (1966)

20. Petter, $C$, and Bourbon, $J$.: Variations de volume du liquide des annexes foetales du rat et du taux de l'hématocrite du sang des vaisseaux vitellins sous l'influence d'une d'eshydration maternelle et de l'adrénaline. C. R Soc. Biol., 161: 2215 (1970)

21. Plas, C., Chapeville, F., and Jacquot, R.: Development of glycogen storage ability under cortisol control in primary cultures of rat fetal hepatocytes. Develop. Biol., 32: 82 (1973)

22. Roehrig, K. L., and Allred, J. B.: Direct enzymatic procedure for the determination of liver glycogen. Anal. Biochem., 58: 414 (1974).

23. Sabata, $\mathrm{V}$. Wolf, $\mathrm{H}$, and Lausmann, $\mathrm{S}$ : The role of free fatty acids, glycerol, ketone bodies and glucose in the energy metabolism of the mother and fetus during delivery. Biol. Neonate, 13: 7 (1968)

24. Sabata, V., Wolf, H., and Lausmann, S.: Glycerol levels in the maternal and umbilical cord blood under various conditions. Biol. Neonate, 15: 123 (1970).

25. Scow, R. O., Chernick, S. S., and Brinley, M. S.: Hyperlipemia and ketosis in the pregnant rat. Amer. J. Physiol., 206: 796 (1964).

26. Shafrir, E., and Gorin, E.: Release of glycerol in conditions of fat mobilization and deposition. Metabolism, 12: 580 (1963).

27. Somogyi, M.: Determination of blood glucose sugar. J. Biol. Chem., 160: 69 (1945).

28. Vernon, R. G., and Walker, D. G.: Glycerol metabolism in the neonatal rat Biochem. J., 118: 531 (1970)

29. Ward, C. J., and Walker, D. G.: Regulation of enzyme development for glycerol utilization by neonatal rat liver. Biol. Neonate, 23: 43 (1973).

30. Widdowson, E. M.: Growth and composition of the fetus and newborn. In: N. S. Assali: Biology of Gestation. Vol. 2, p. 1 (Academic Press, New York, 1968).

31. Yeung. D., and Oliver. I. T.: Gluconeogenesis from amino acids in neonatal rat. Biochem. J., 103: 744 (1967)

32. Yeung, D., and Oliver, I. T.: Development of gluconeogenesis in neonatal rat liver: Effect of premature delivery. Biochem. J., 105: 1229 (1967)

33. C. E. A. Saclay. France.

34. Actigraph III, Nuclear Chicago, Chicago, Ill

35. Radiochemical Centre, Amersham, UK

36. Gratitude is expressed to Dr. A. Jost for discussion and review of the manuscript and to Mrs. Mallet for technical assistance.

37. Requests for reprints should be addressed to: M. Gilbert, M.D., Laboratoire de Physiologie du Développement du Collège de France, Université Pierre et Marie Curie. 9 quai Saint-Bernard, 75230 Paris Cedex 05, France.

38. Received for publication Feburary 3,1976.

39. Accepted for publication July 29, 1976. 